\title{
Molecular Docking of Compounds in Moringa oleifera Lam with Dipeptidyl Peptidase-4 Receptors as Antidiabetic Candidates
}

Indah Permata Rendi, Gabriella Josephine Maranata*, Hasna Chaerunisa, Nurulita Nugrahaeni, Siti Sarah Alfathonah Department of Pharmaceutical Analysis and Medicinal Chemistry, Faculty of Pharmacy, Padjadjaran University, Bandung, Indonesia

*Corresponding author: gabriella17003@mail.unpad.ac.id

Submitted: 1 January2021

Accepted: 16 June 2021

Published: 30 November 2021

\begin{abstract}
Background: Diabetes mellitus (DM) type 2 is a metabolic disorder that needs special attention because it can damage several organs if the severity increases. One of the treatments for diabetes mellitus (DM) type 2 is by inhibiting Dipeptidyl peptidase 4 (DPP-IV) with vildagliptin to prolong the hypoglycemic effect of GLP-1 and GIP. Objective: In the search for candidate compounds as new antidiabetic compounds, an in silico test with molecular docking was carried out to predict the antidiabetic activity of 10 Moringa oleifera Lam (MO) plant compounds at the DPP-IV receptor (PDB ID: 6BIE). Method: The study was conducted using the molecular docking method. Result: Validation of the vildagliptin DPP-IV ligand obtained free energy values of $-9.27 \mathrm{kcal} / \mathrm{mol}$ and RMSD 1.49 $\AA$ (RMSD $<2 \AA)$, then tested with 10 test compounds obtained 8 test compounds that have the potential to be antidiabetic. Conclusion: Serpentine compounds have better potential as an antidiabetic drug than other target compounds because they have the closest Gibbs energy $(\Delta G)$ value to the natural ligand of Vidaglibtin, which is $7.90 \mathrm{kcal} / \mathrm{mol}$. This value is still lower than the free energy of vildagliptin, which is $-9.37 \mathrm{kcal} / \mathrm{mol}$. Therefore further testing is needed to ensure the potential of the compound as a candidate for antidiabetic drugs.
\end{abstract}

Keywords: diabetes, molecular docking, DPP4, Moringa oleifera Lam., vildagliptin

\begin{abstract}
Abstrak
Pendahuluan: Diabetes melitus (DM) tipe 2 merupakan penyakit gangguan metabolisme yang perlu mendapatkan perhatian khusus karena dapat merusak beberapa organ jika keparahan meningkat. Salah satu pengobatan DM tipe 2 dengan melakukan penghambatan Dipeptidyl peptidase 4 (DPP-IV) yaitu dengan vildagliptin sehingga dapat memperpanjang efek hipoglikemik GLP-1 dan GIP. Tujuan: Dalam pencarian kandidat senyawa sebagai antidiabetes baru, maka dilakukan uji in silico dengan penambatan molekuler untuk memprediksi aktivitas antidiabetes 10 senyawa tanaman Moringa oleifera Lam. (MO) pada reseptor DPP-IV (PDB ID: 6B1E). Metode: Penelitian dilakukan dengan metode doking molekular. Hasil: Validasi ligan vildagliptin DPP-IV didapatkan nilai

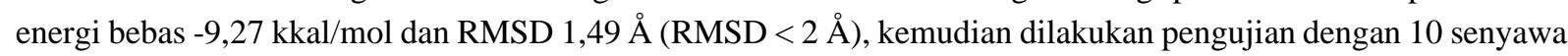
uji didapatkan 8 senyawa uji yang berpotensi sebagai antidiabetes. Kesimpulan: Senyawa serpentin memiliki potensi lebih baik sebagai kandidat obat antidiabetes dibandingkan senyawa target lainnya karena memiliki nilai energi bebas Gibbs $(\Delta \mathrm{G})$ paling mendekati ligan alami Vidaglibtin yaitu sebesar -7,90 kkal/mol. Nilai ini masih lebih rendah dibandingkan energi bebas vildagliptin yaitu $-9,37 \mathrm{kkal} / \mathrm{mol}$, oleh karena itu perlu dilakukan pengujian lebih lanjut untuk memastikan potensi senyawa sebagai kandidat obat antidiabetes.
\end{abstract}

Kata kunci: diabetes, doking molekuler, DPP4, Moringa oleifera Lam., vildagliptin

\section{INTRODUCTION}

Diabetes Mellitus (DM) is a metabolic disorder characterized by long-term high blood glucose levels.
This disease has become one of the main health problems in the world and needs special attention. Over time, DM can damage the heart, kidney, and nervous 
system. DM was divided into two categories (type 1 and 2) based on patients' absolute or relative insulin deficiency. According to International Diabetes Federation (IDF), in 2019, nearly half a million people in the world, approximately 463 million people, were living with diabetes. If this problem persists, it is estimated that the number will continue to increase to 13.7 million in 2030 and 16.9 million in 2045 (IDF, 2019; Yang et al., 2020).

Currently, it takes 10 - 15 years to develop new drugs, and this process costs much money (Dimasi et al., 2016). Due to the lack of certain drug properties, such as poor pharmacokinetics and toxicity problems that appear in clinical trials, only one drug out of 10,000 candidates can eventually be marketed during the drug development process (Pink et al., 2005). With the development of computer technology, structure-based virtual screening such as molecular docking has become one of the methods that can be used for drug discovery (Ma et al., 2013). The advantage of this method is that candidate compounds that have low drug ability can be removed, lowering costs and increasing efficiency (Katsuno et al., 2015).

Molecular docking analysis is a drug discovery technology based on simulating interactions between ligands and target proteins. The structural libraries of compounds from various sources were screened and analyzed by pharmacophore matching and molecular docking methods, based on the drug-binding site of the target protein (Meng et al., 2011). Virtual drug screening based on molecular docking technology has become a popular and effective drug development strategy. Docking was developed to be a tool for drug discovery through an in silico approach.

Several medicinal plants have been used as therapeutic agents for various diseases. Moringa oleifera (MO) is a significant medicinal plant because it is traditionally used to treat various health disorders, including diabetes mellitus (DM) type 2 (Farooq et al., 2012). MO has long been called the "Tree of Life" and "Magic Tree" in the tropics and subtropics because it can be used as a food and an essential traditional medicine in Asia to treat diabetes and obesity (Moyo et al., 2011).

Currently, there are very few studies on the pharmacological activity of the chemical elements contained in MO and these studies this research is limited to the exploration of crude extract bioactivity. Somova et al. (2003) found that MO extract had antihypertensive and hypoglycemic activity. Most studies on the hypoglycemic activity of MO extracts have not identified individual components with specific molecular mechanisms. Different parts of MO are enriched with carotenoids, alkaloids, flavonoids, glycosides, anthocyanins, anthraquinones, saponins, steroids, tannins and terpenoids (Patel et al., 2014).

Zainab et al. (2020) have conducted an in silico study using molecular docking on 10 MO plant compounds, namely Anthraquinone, Laurifolin (flavonoid), Serpentine (alkaloid), 2Phenylchromenylium anthocyanin, Alpha-Carotene, Sitogluside Glycoside, A-Phenolic Steroid, Saponin, Hemlock Tannins and terpenoids EA-I. The results show that 5 phytochemical compounds screened from MO plants are effective as potential therapeutic drug candidates to treat diabetes mellitus at the Crystal Structure of Insulin kinase receptors.

In this study, molecular docking was carried out to predict the antidiabetic activity of the $10 \mathrm{MO}$ plant compounds with different receptors, namely the DPP-IV receptor. Based on drug-like properties and molecular docking evaluation principles, inhibition of DPP-IV was confirmed by in vitro experiments. DPP-IV, also called $\mathrm{CD} 26$, is a serine protease. As a treatment for type 2 diabetes, DPP-4 inhibitors inhibit the degradation of incretins, GLP-1 and GIP (Juillerat, 2013). There are DPP-IV inhibitors currently on the market, such as sitagliptin and vildagliptin. The DPP-IV inhibitors currently on the market have significant hypoglycemic effects (Makrilakis, 2019).

\section{MATERIALS AND METHODS}

\section{Materials}

The materials in this molecular docking are the structure of the compounds contained in MO, namely Anthraquinone, Laurifolin (flavonoids), Serpentine (alkaloids), 2-Phenylchromenylium anthocyanins, Alpha-carotene, Sitogluside glycosides, A-Phenolic Steroids, Saponins, Hemlock tannins, and Terpenoid EA-I. The structures were made in $2 \mathrm{D}$ and $3 \mathrm{D}$ form using the ChemDraw Ultra 12 application. DPP-IV receptor downloaded from the Protein Data Bank (PDB) database with ID 6B1E.

\section{Tools}

This study was performed using ASUS Windows 10 equipped with Intel ${ }^{\circledR}$ Core $^{\mathrm{TM}}$ i3-4030U CPU @ 1.90 $\mathrm{GHz}$, 64-bit operating system, $84.7 \mathrm{~GB}$ hard drive capacity, and 2.00 GB RAM memory. The software includes (1) Chemdraw ${ }^{\circledR}$ Ultra 12.0 free trial (Cambridge Soft Corporation, downloaded at www.cambridgesoft.com) used to draw ligand structures in 2D and 3D; (2) Autodock 4.2 (downloaded from http://autodock.scrips.edu); (3) BIOVIA 
Discovery Studio 2016, used for visualization of protein data bank (PDB) complexes.

\section{Methods}

This study was performed to find new antidiabetic potential drugs in $\mathrm{MO}$ plant compounds using the in silico method, namely molecular docking including preparation of target receptors, ligand preparation, molecular docking validation, and molecular docking (Muchtaridi et al., 2017).

\section{Preparation of target receptor}

DPP-IV receptor was obtained from Protein Data Bank (PDB ID: 6B1E) with a resolution of $1.77 \mathrm{~A}$. The receptor was separated (using Discovery Studio) by removing the water molecules and the ligand molecules. The obtained protein molecule was saved in the receptor.pdb file format. The receptor that will be tested was prepared using the AutoDockTools application by adding a hydrogen group and increasing the Kollman charge. The receptor was saved in the receptor.pdbqt file format.

\section{Ligand preparation}

The ligands were separated (using Discovery Studio) by removing water molecules and protein molecules. The obtained ligand molecules were saved in the ligand.pdb file format. The ligands that will be tested were prepared using the AutoDockTools application by adding a hydrogen group, merging the non-polar group, and increasing the Gasteiger charge. Then, detect and select the root. After that, choose torsion and set the number of torsions. The ligands were saved in the ligand.pdbqt file format.

\section{Validation of molecular docking}

Grid parameters are used to define region boundaries in the molecular docking process, and the receptor's active site will be covered to improve docking efficiency. These parameters were created in the grid menu of AutoDockTools, and the file was saved in .gpf file format. The AutoGrid process ran these parameters, and the file was saved in glg format.

Docking parameters were created through the docking menu. Then, the receptor and ligand file were selected in pdbqt format. The Lamarckian parameter was added and the file was saved in dpf format.

The receptor.pdbqt file and ligand.pdbqt was inserted. Select the ligand, prepare the grid box (x: 36.602; y: 50.275; z: 35.416) and save in gpf format. Sets the receptor's rigid filename. The ligand and the parameters of the Genetic Algorithm were chosen. Make the number of GA runs 50. After choosing the docking parameters, the file was saved in dpf format using Lamarckian GA. The validation result of molecular docking was interpreted as the Root Mean Square Deviation (RMSD) value.

\section{Molecular docking}

After obtaining the grid box parameters and RMSD values, molecular docking of the test ligands and target receptors was carried out in the same steps. The molecular docking results are the ligand's Gibbs energy $(\Delta \mathrm{G})$, the number of clusters, the inhibition constant $(\mathrm{KI})$, and the interactions involved in the $2 \mathrm{D}$ and $3 \mathrm{D}$ forms by opening BIOVIA to see the bonds in the receptor and ligand.

\section{RESULT AND DISCUSSION}

A total of 10 compounds are contained in the MO plant, namely, Anthraquinone, Laurifolin (flavonoid), Serpentine (alkaloid), 2-Phenylchromenylium anthocyanin, Alpha-carotene, Sitogluside glycoside, APhenolic Steroid, Saponin, Hemlock tannin, and Terpenoid EA-I were selected to in silico study its activity at the DPP-IV receptor. The DPP-IV receptor in complex with vildagliptin (PDB ID: 6B1E) was selected in the present study based on the already in the organism Homo sapiens and the method used is the $\mathrm{x}$-ray diffraction method. The structure that has been made with this method has a resolution of $1.77 \AA$, which is a good value. The free R-value that is owned is 0.186 , and the working $R$-value is 0.161 . This value itself can be used as a factor in evaluating the quality of molecular crystals. The working R-value can also be used to measure the deviation between the intensity of the observed diffraction pattern and the intensity of the calculated model prediction. The R-value of good working is smaller than 0.20 , and the DPP-IV receptor in the complex with vildagliptin has a smaller value than the requirement, so it can be said to be ideal.

The protein was downloaded using PDB as a database for data on the three-dimensional structure of large biological molecules, such as proteins and nucleic acids. DPP-IV is a proteolytic enzyme or protease found on the cell surface. DPP-IV inhibitor enzymes play a role in maintaining glucose balance by proteolytic inactivation of incretins so that this enzyme will improve glucose tolerance and pancreatic islet cell function in diabetic patients. One of the pathogeneses of DM is an increase in the activity of the DPP-IV enzyme, which results in impaired glucose metabolism in the body. Therefore, several drugs are designed with the mechanism of the DPP-IV inhibitory pathway to increase the signal on insulin secretion and restore normal glucose metabolism. 
The initial step of receptor preparation was carried out using the software BIOVIA Discovery Studio to separate ligand and water molecules with receptors because water molecules can cause the molecular docking process to become more complex and allow hydrogen bonds to occur with compounds other than ligand. The results of this process are saved in the receptor .pdb file format. The next step is the preparation of the ligand with vildagliptin as the standard ligand. The ligands to be tested are Anthraquinone, Laurifolin (flavonoid), Serpentine, which belongs to the alkaloid group, 2-Phenylchromenylium anthocyanin, Alphacarotene, Cytogluside glycoside, A-Phenolic Steroids, Saponins, Hemlock tannins, and Terpenoids EA-I. 2D structure modelled with software Chemdraw Ultra and optimized geometric design into 3D using software Chem $3 D$ then saved as a .pdb file. Ligand optimization is done by adding the charge Gasteiger using the software Autodock Tools and then merging nonpolar so that only the polar hydrogen atoms appear. Before the ligand is docked to the receptor, it is necessary to identify the active pocket binding to the receptor using the parameter grid.

Then, the validation process of the molecular docking method was carried out. Validation of computational methods is carried out to ensure that the method used has met the validity requirement so that it can be used for another molecular testing. In the docking process, the standard ligand separated from the receptor is redocking, namely vildagliptin and the test ligand with the DPP-IV receptor. The grid box (bond area) is determined to limit the search space for the ligand conformation in the docking process. The resulting grid box is $x=36.602 ; y=50.275 ; z=35.416$. The results of the validation follow the requirements of $1.49 \AA$ (RMSD requirements $<2 \AA$ ) so that it can be said that the system is valid and ready for the next process.

Parameters used to see the interaction of the test compound with the receptor include Gibbs free energy, inhibition constant, and the interaction between the ligand and receptor complex. The test results are used as a standard to determine which compounds have similar activity at the DPP IV receptor.

Molecular docking between the standard ligand vildagliptin and the DPP-IV receptor resulted in a Gibbs free energy of $-9.37 \mathrm{kcal} / \mathrm{mol}$ with an inhibition constant of $135.65 \mathrm{uM}$ (Table 1). Based on the test results on ten compounds in the MO plant, the serpentine compound (Figure 1) has a Gibbs energy value of $-7.90$ $\mathrm{kcal} / \mathrm{mol}$ with a constant inhibition value of $1.61 \mathrm{uM}$. This value is indeed not more damaging than vildagliptin but better than other compounds. It is known that the more negative the Gibbs free energy value $(\Delta \mathrm{G})$ indicates a good level of stability between the ligand and the receptor so that it will form a stronger bond (Du et al., 2016). In addition, the value of the inhibition constant is also directly proportional to the Gibbs energy; the smaller the case, the smaller the inhibition constant, which indicates the bond interaction between the ligand and receptor is getting stronger ( Du et al., 2016; Brooks et al., 2009). The value of the inhibition constant shows the concentration required for a ligand to affect the receptor (Cortés et al., 2001; dos Reis et al., 2013).

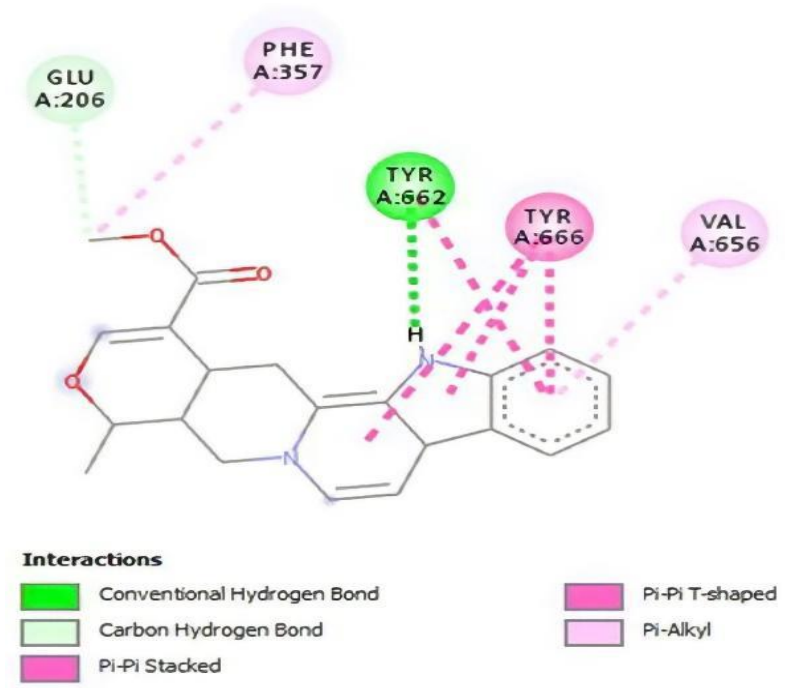

Figure 1. Interaction between serpentin and DPP4 
Table 1. Parameters of molecular docking of the test compound with the DPP4 enzyme

\begin{tabular}{|c|c|c|c|c|c|}
\hline \multirow{2}{*}{ No. } & \multirow{2}{*}{ Compound } & \multirow{2}{*}{$\begin{array}{c}\text { Free energy } \\
(\mathrm{kcal} / \mathrm{mol})\end{array}$} & \multirow{2}{*}{$\begin{array}{l}\text { Inhibition } \\
\text { constant } \\
\text { (uM) }\end{array}$} & \multicolumn{2}{|c|}{ Interaction with Amino Acid } \\
\hline & & & & Hydrogen bond & Hydrophobic bond \\
\hline 1. & Vildagliptin & -9.37 & 135.65 & Tyr547 & $\begin{array}{c}\text { Glu205, Glu206, } \\
\text { Asp663, Tyr666, Tyr662 }\end{array}$ \\
\hline 2. & Serpentine & $-7,90$ & 1,61 & Tyr662 & $\begin{array}{l}\text { Tyr666, Glu206, Val656, } \\
\text { Phe357 }\end{array}$ \\
\hline 3. & A-phenolic steroid & $-6,67$ & 12,97 & Ser630 & Phe 357 , Tyr666 \\
\hline 4. & $\begin{array}{c}\text { 2-Phenylchromenylium } \\
\text { Anthocyanin }\end{array}$ & $-6,44$ & 19,12 & Ser 630, Tyr547 & His740, Trp629 \\
\hline 5. & Antraquinone & $-6,35$ & 22,12 & $\begin{array}{c}\text { Tyr666, Tyr 662, Asn } \\
710\end{array}$ & Glu206 \\
\hline 6. & Hemlock tannin & $-6,31$ & 23,89 & Glu205, Tyr662 & Phe357, His740, Arg125 \\
\hline 7. & Terpenoid EA-I & $-6,12$ & 32,91 & & $\begin{array}{c}\text { Tyr666, Val711, Phe357, } \\
\text { Val656, Tyr631, } \\
\text { Tyr662, Phe357 }\end{array}$ \\
\hline 8. & Laurifolin & $-5,56$ & 84,15 & Ser630 & Glu206, Phe357, Tyr547 \\
\hline 9. & Sitogluside glycoside & $-5,18$ & 159,26 & $\begin{array}{l}\text { Arg125, Glu205, } \\
\text { His126 }\end{array}$ & $\begin{array}{l}\text { Glu 206, His740, } \\
\text { Tyr666, Tyr662 }\end{array}$ \\
\hline 10. & Saponin & +1178.77 & unavailable & - & - \\
\hline 11. & Alpha-carotene & +214551.80 & unavailable & - & - \\
\hline
\end{tabular}

Then, the visualisation results to see the presence of residues that bind between the standard ligand vildagliptin and the DPP-IV receptor, hydrogen bond interactions occur in Tyr547 and hydrophobic bonds interactions Glu205, Glu206, Asp663, Tyr666, and Tyr662 (Figure 2). Based on the hydrogen bonds formed in the 10 test compounds, 2-Phenylchromenylium Anthocyanin has a good affinity for the DPP-IV receptor on the amino acid residue Tyr547. This result is consistent with the hydrogen bonding interaction with the standard ligand vildagliptin on the amino acid residue Tyr547 (Figure 3). An interaction occurs at the same amino acid residue so that 2-Phenylchromenylium Anthocyanin is predicted to have similar biological activity to vildagliptin (Muttaqin, 2019).
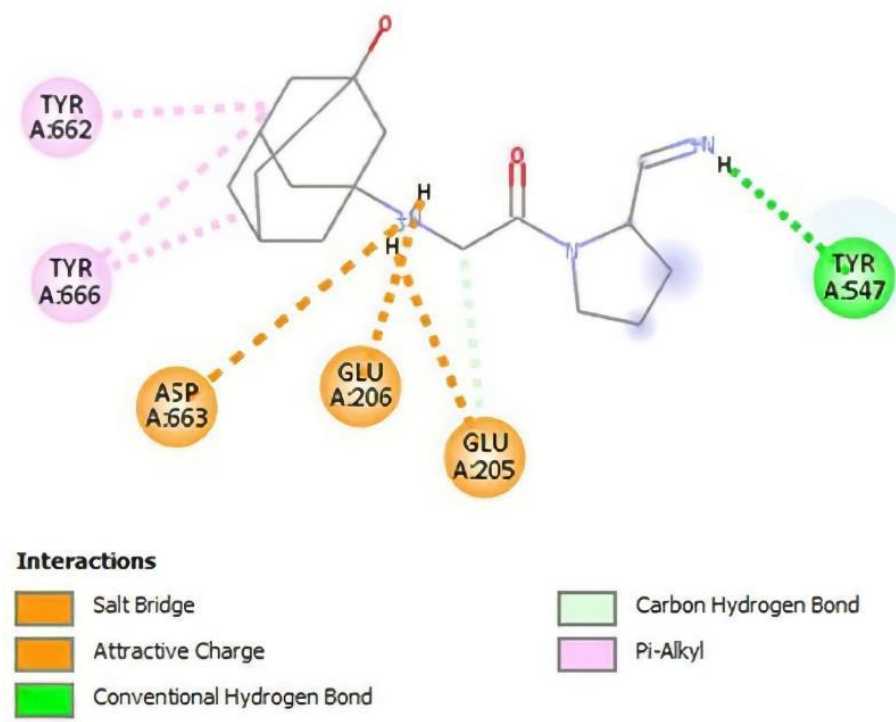

Figure 2. Interaction between vildagliptin and DPP4 

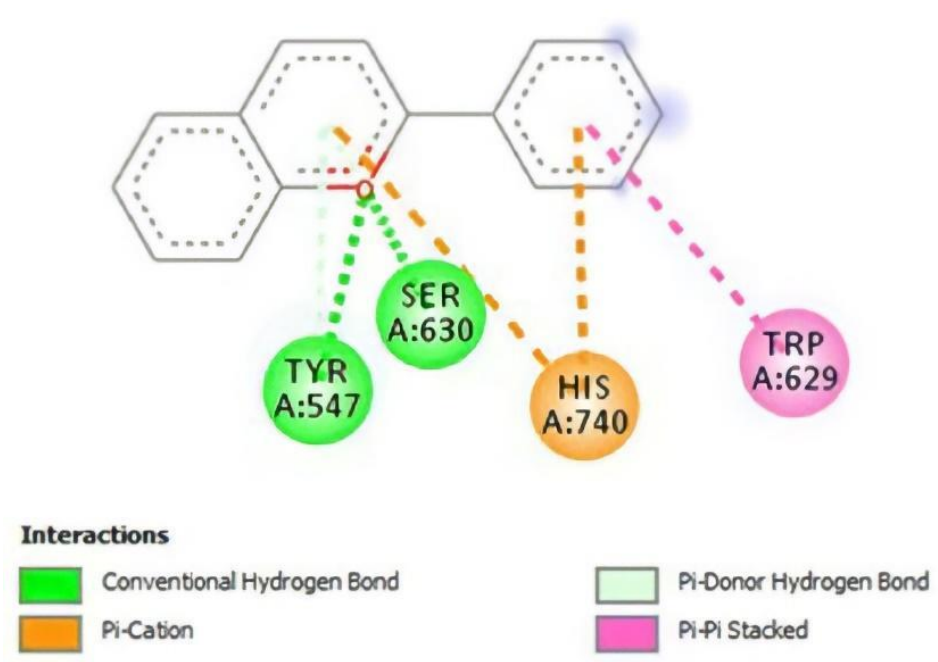

Figure 3. Interaction between 2-phenylchromenylium anthocyanin and DPP4

Hydrogen bonding contributes to the affinity of a molecule for the target protein, thereby forming electrostatic interaction (hydrogen donor and acceptor) (Murray, 2003; Bissantz et al., 2010). The number of hydrogen bond donors and acceptors indicates that the higher the hydrogen bonding capacity, the higher the energy required for the absorption process to occur (Syahputra et al., 2011).

The value of Gibbs free energy between the ligandreceptors is not only influenced by the presence of hydrogen bonds but is also influenced by several factors such as hydrophobic and electrostatic interactions. Hydrophobic interactions are interactions that occur between nonpolar groups. This bond is an essential bond in the process of combining the nonpolar region of the drug molecule with the nonpolar region of the biologic receptor, where the nonpolar part of the drug molecule that is unable to dissolve in water will combine with the surrounding water molecules through hydrophobic bonds form a quasi-crystalline structure. This hydrophobic bond also has a significant role in determining the binding strength between protein and ligand (Bharathi et al., 2014; Chakraborty et al., 2014).

It is known from the results of molecular docking that serpentine compounds have Gibbs free energy $(\Delta \mathrm{G})$, which is closest to natural ligand compounds of vildagliptin. This condition can be influenced because there are two residues in the hydrophobic interaction between serpentine and vildagliptin, namely Tyr666 and Glu206 residues, while the 2-Phenylchromenylium Anthocyanin compound does not have the same residue as vildagliptin in hydrophobic interactions. The interaction of the amino acid residues involved can allow for contact between the ligand and the DPP-IV receptor to have inhibitory activity.
By comparing the results of the interactions that occur and the Gibbs free energy value $(\Delta G)$ of vildagliptin with 10 test compounds, serpentine compounds have the greatest potential as antidiabetic drug candidates compared to other test compounds because they have the Gibbs free energy $(\Delta \mathrm{G})$ which is closest to the energy free of Gibbs $(\Delta \mathrm{G})$ vildagliptin. However, further tests are needed to ensure that these compounds have the most potential candidates for antidiabetic drugs, such as in vitro, in vivo, and clinical trials.

\section{CONCLUSION}

The compound contained in Moringa oleifera (MO), namely serpentine has better potential as an antidiabetic drug candidate when compared to other target compounds because it has a Gibbs free energy value $(\Delta \mathrm{G})$ which is closest to the natural ligand of Vidaglibtin, which is $-7.90 \mathrm{kcal} / \mathrm{mol}$. This value is still lower than vildagliptin, which is $-9.37 \mathrm{kcal} / \mathrm{mol}$. Therefore, it is necessary to conduct further experiments to ensure that these compounds have the most potential as candidates for antidiabetic drugs, such as in vitro, in vivo, and clinical trials.

\section{ACKNOWLEDGEMENT}

This research is part of the Department of Pharmaceutical Analysis and Medicinal Chemistry, Faculty of Pharmacy, Padjadjaran University. Thanks are given to Prof. apt. Muchtaridi, Ph.D. and Dr. apt. Sandra Megantara, M.Farm. from Padjadjaran University who has guided this research. 


\section{REFERENCES}

Bharathi, A., Roopan, S. M., Vasavi, C. S., Munusami, P., Gayathri, G. A. \& Gayathri, M. (2014). In Silico Molecular Docking and In Vitro Antidiabetic Studies of Dihydropyrimido [4,5a]acridin-2-amines. BioMed Research International; 2014; 1-10.

Bissantz, C., Kuhn, B. \& Stahl, M. (2010). A Medicinal Chemist's Guide to Molecular Interactions. Journal of Medicinal Chemistry; 53; 5061-5084.

Brooks, B. R., Brooks, C. L., Mackerell, A. D., Nilsson, L., Petrella, R. J., Roux, B., Won, Y., Archontis, G., Bartels, C., Boresch, S., Caflisch, A., Caves, L., Cui, Q., Dinner, A. R., Feig, M., Fischer, S., Gao, J., Hodoscek, M., Im, W. \& Karplus, M. (2009). Journal of Computational Chemistry; 30; 1545-1614.

Chakraborty, C., Hsu, M. J. \& Agoramoorthy, G. (2014). Understanding the Molecular Dynamics of Type-2 Diabetes Drug Target DPP-4 and its Interaction with Sitagliptin and Inhibitor DiprotinA. Cell Biochemistry and Biophysics; 70; 907922.

Cortés, A., Cascante, M., Cárdenas, M. L. \& CornishBowden, A. (2001). Relationships Between Inhibition Constants, Inhibitor Concentrations for $50 \%$ Inhibition and Types of Inhibition: New Ways of Analysing Data. Biochemical Journal; 357; 263- 268.

Dimasi J. A., Grabowski H. G. \& Hansen R.W. (2016). Innovation in the Pharmaceutical Industry: New Estimates of R\&D costs. Journal of Health Economics; 47; 20-33.

Dos Reis, M. B. G., Manjolin, L. C., Maquiaveli, C. D. C., Santos-Filho, O. A. \& Da Silva, E. R. (2013). Inhibition of Leishmania (Leishmania) Amazonensis and Rat Arginases by Green Tea EGCG, (+)-Catechin and (-)-Epicatechin: a Comparative Structural Analysis of EnzymeInhibitor Interactions. PloS one; 8; e78387e78387.

Du, X., Li, Y., Xia, Y. -L., Ai, S. -M., Liang, J., Sang, P., Ji, X. -L. \& Liu, S. -Q. (2016). Insights Into Protein-Ligand Interactions: Mechanisms, Models, and Methods. International Journal of Molecular Sciences; 17; 1-34.

Farooq, F., Rai, M., Tiwari, A., Khan, A. A. \& Farooq, S. (2012). Medicinal Properties of Moringa oleifera: An Overview of Promising Healer. Journal of Medicinal Plants Research; 6; 43684374.

P-ISSN: 2406-9388

E-ISSN: 2580-8303
IDF. (2019). Diabetes Atlas Edisi 9. Brussels: International Diabetes Federation.

Juillerat, J. L. (2013). Dipeptidyl Peptidase IV and Its Inhibitors: Therapeutics for Type 2 Diabetes and What Else? Journal of Medicinal Chemistry; 57; 2197-2212.

Karaman, B., Alhalabi, Z., Swyter, S., Mihigo, S., Andrae-Marobela, K., Jung, M., Sippl W. \& NtieKang F. (2018). Identification of Bichalcones as Sirtuin Inhibitors by Virtual Screening and In Vitro Testing. Molecules; 23; 1-10.

Katsuno, K., Burrows J. N., Duncan, K., Van, H. R. H., Kaneko, T., Kita, K., Mowbray, C. E., Schmatz, D., Warner, P. \& Slingsby B. (2015). Hit and Lead Criteria in Drug Discovery for Infectious Diseases of the Developing World. Nature Reviews Drug Discovery; 14; 751-758.

Ma, D. -L., Chan, D. S. -H., Leung C.-H. (2013). Drug Repositioning by Structure-Based Virtual Screening. Chemical Society Reviews; 42; 21302141.

Makrilakis, K. (2019). The Role of DPP-4 Inhibitors in the Treatment Algorithm of Type 2 Diabetes Mellitus: When to Select, What to Expect. International Journal of Environmental Research and Public Health; 16; 1-20.

Meng, X. -Y., Zhang H. -X., Mezei, M. \& Cui, M. (2011). Molecular Docking: A Powerful Approach for Structure-Based Drug Discovery. Current Computer-Aided Drug Design; 7; 146157.

Moyo, B., Masika, P. J., Hugo, A., Muchenje, V. (2011). Nutritional Characterization of Moringa (Moringa oleifera Lam.) Leaves. Food Chemistry; 10; 12925-12933.

Muchtaridi, M., Syahidah, H. N., Subarnas, A., dkk. (2017). Molecular Docking and 3DPharmacophore Modeling to Study the Interactions of Chalcone Derivatives with Estrogen Receptor Alpha. Pharmaceuticals; 10; $1-12$.

Murray, R. K. (2003). Harpers Biochemistry. USA: Prentice Hall International INC.

Muttaqin, F. Z. (2019). Molecular Docking and Molecular Dynamic Studies if Stilbene Derivative Compounds as Sirtuin-3 (SIRT3) Histone Deacetylase Inhibitor on Melanoma Skin Cancer and Their Toxicities Prediction. Journal of Pharmacopolium; 2; 112-121.

Patel, P., Patel, N., Patel, D., Desai, S. \& Meshram, D. (2014). Phytochemical Analysis and Antifungal 
Activity of Moringa oleifera. International Journal of Pharmacy and Pharmaceutical Sciences; 6; 144-147.

Pink, R., Hudson A., Mouriès M. -A. \& Bendig, M. (2005). Opportunities and Challenges in Antiparasitic Drug Discovery. Nature Reviews Drug Discovery; 4; 727-740.

Somova, L. I., Shode, F. O., Ramnanan, P. \& Nadar, A., (2003). Antihypertensive, Antiatherosclerotic and Antioxidant Activity of Triterpenoids Isolated from Olea europaea, Subspecies Africana Leaves. Journal of Ethnopharmacology; 84; 299-305.

Syahputra, G., Ambasari, L. \& Sumaryada, T. (2011). Simulasi Docking Kukurmin Enol, Bisdemetoksikurkumin dan Analognya sebagai
Inhibitor Enzim 12-Lipoksigenase. Jurnal Biofisika; 10; 55-67.

Yang, Y., Shi, C. -Y., Xie, J., Dai, J. -H., He, S. -L. \& Tian, Y. (2020). Identification of Potential Dipeptidyl Peptidase (DPP)-IV Inhibitors among Moringa oleifera Phytochemicals by Virtual Screening, Molecular Docking Analysis, ADME/T-Based Prediction, and In Vitro Analyses. Molecules; 25; 1-12.

Zainab, B., Ayaz, Z., Alwahibi, M. S., Khan, S., Rizwana, H., Soliman, D. W., Alawaad, A. \& Mehmood, A. A. (2020). In-silico Elucidation of Moringa oleifera Phytochemicals against Diabetes Mellitus. Saudi Journal of Biological Sciences; 27; 2299-2307. 